\title{
Effects of Dual Sector Inflation Across Income Levels in Pakistan
}

\author{
USMAN AFRIDI, ASGHAR QADIR and JAVED ZAKI*
}

\section{INTRODUCTION}

In this paper we will be primarily concerned with the effect of inflation on different income groups. Putting it another way, we are looking for an answer to the question, "What have been the differences in the degree of inflation in various income groups in Pakistan?".

Though it is not in the purview of this paper to go into the causes and cures of inflation, we feel that it is necessary to give a brief discussion about inflation in general. The classical economists believed that inflation was a purely monetary phenomenon. The theory developed was popularly termed the 'quantity theory of money' and the basic relationship postulated was that the rate of inflation is equal to the rate of growth of money supply. Keynes [6] attacked the quantity theory of money, stating that the immediate source of inflation was the excess of desired expenditure over output and thus established the income-and-expenditure approach to the determination of the level of economic activity and prices. Later, however, Keynes [7] addressed himself to the effects of inflation and advanced a theory which has since become a basis for the 'inflationary gap' models.

The redistribution of income plays an important role in Keynes's theory of inflation. According to him, the process of inflation transfers income from workers (low-income groups) to profiteers (high-income groups). Neo-Keynesian developments $[4 ; 16]$ identified the presence of money-illusion in the labour market which serves to transfer income from those who spend proportionately more on consumption (lower-income groups) to those who spend less (higher-income groups).

*The authors are, respectively, Research Economist at the Pakistan Institute of Development Economics (PIDE), Islamabad, Associate Professor of Mathematics at the Quaid-i-Azam University, Islamabad, and Research Demographer at the PIDE. They would like to thank Prof. Syed Nawab Haider Naqvi for his comments and helpful suggestions. The authors also acknowledge the valuable editorial help of Syed Hamid Hasan Naqavi. 
Inflationary gap models assumed that inflation would lower consumption expenditures by moving income from lower-income groups to higher-income groups. Flattening the consumption function would lower aggregate demand in the economy and thus reduce inflation by closing the inflationary gap. All neo-Keynesian theories and models assume that after the down-turn in an economic cycle, equilibrium will be restored automatically and inflation will fall to zero.

These models have, of course, all been constructed for developed economies where consumption expenditure, at even the lowest level, is still fairly high. For underdeveloped countries, such as Pakistan, the lowest-income groups are at the level of the lowest possible sustainable consumption. The tables presented in this paper show that these groups in fact spend more than they earn. What would happen if the structure of inflation further reduces their real incomes? We contend that consumption would remain static and further borrowing would result. Thus the increase in money supply from increased borrowing would enhance the inflationary gap. Evidence on inflation for Pakistan supports our hypothesis. Since 1973, in spite of high inflation, there has been no evidence of a movement towards equilibrium, or of a flattening of the consumption function, or of a reduction of aggregate demand. In fact, all evidence is to the contrary. It has been suggested, however, that the rate of inflation must be non-decreasing [15].

Monetarists generally tend to believe that inflation has an egalitarian effect on incomes, while Keynesian theorists contend that it has the opposite effect. Bach and Stephenson [3] and Nordhaus [9] lent their support to the view that inflation contributes to equalizing of income. Piachaud [14], Muellbaeur [8] and Williamson [17] found that in the UK and the USA, the lower-income groups had experienced a greater increase in proportionate expenditure than was experienced by the higherincome groups through inflation. In all these studies, however, the differences in the degrees of inflation in various income groups are inadequate for any strong conclusions. Williamson [17], in examining inflation during periods when inequalities in incomes were increasing, found that the prices of necessities increased at a much higher rate than that of the prices of luxuries. He found that virtually all the regressive price impact could be attributed to the prices of food.

It has been shown by Afridi and Qadir [1] that for Pakistan and, as a rule, for other low per capita income countries [2], the single inflation rate cannot meaningfully pertain to a representative basket of goods. Both these studies have suggested that for the low-income countries considered, a two-sector analysis for inflation is necessary for any meaningful use of statistics. For the developed countries studied, the single inflation rate was found to be a meaningful aggregation. It seems reasonable to assume that this will be the case for all developed countries.

In this paper we examine how inflation affects consumers at different levels of income in the light of the two-sector disaggregation. Generally, one would expect the lower-income groups to spend a greater proportion of their incomes on food than that spent by the higher-income groups. If, in an economy, the price of the basket of food goods inflates at a higher rate than that of the price of the basket of non-food goods, one would expect the economic system to be structured against the interests of the lowest-income groups. We have tested this hypothesis for Pakistan and have found that inflation increases the existing inequalities in the economy.

\section{Methodology and Selection of Data}

We have used the results of the study by Afridi and Qadir [1] for examining the effect of a two-sector aggregation of inflation. It was found in that study that while the single-inflation index close to 11 percent per annum was an unsatisfactory index, the two-sector indices of food commodities inflating at a rate of nearly 17 percent and of other commodities inflating at the rate of about 6 percent per annum were satisfactory aggregations. In examining inflation in Pakistan, we have used the Micro-Nutrient Survey of Pakistan, 1976-1977 [11] conducted by the Planning Commission, since it deals with the period cosidered in [1].

We arranged the households at different income levels and disaggregated expenditures into those for food and those for non-food (Table 1, Cols. 3 and 4). Using the dual-sector-inflation model given in [1], we weighted the two sets of expenditures (Table 1, Cols. 6 and 7) and thus obtained the inflation rates for each set (Table 1, Cols. 9 and 10). By adding the two, we obtained the inflation faced by households of different income groups through the nature of their expenditures. As households have different sizes and as consumption behaviour is increasingly measured on a per capita basis, we arranged consumers at different income levels, and, by weighting the two sets of expenditures, obtained the inflation faced by consumers.

It may be argued that neither of the two measures mentioned above is the best representative of the low-income consumer behaviour and that to get a clear picture of the low-income consumer behaviour a standard size of households as a unit of measurement is required. As such, we took the two largest sets of households from the sample: 5-member households and 6-member households. For both sets we arranged the households by income levels and repeated the earlier process.

Consider now a high-income consumer. After meeting his expenditure on food and on other commodities, he has some money left over. He can do one of two things: either he invests in the acquisition of capital goods, or he increases his personal savings. In the presence of inflation, both these activities have a positive effect on his real income. This positive effect amounts to negative inflation from the viewpoint of high-income consumers. As the positive effect through the acquisition of capital goods is difficult to measure, we shall assume that all that is not consumed is, in fact, saved. We have used two rates of interest: 6.5 percent and 12 percent. 
These rates of interest are close to the actual interest rates of savings and timedeposit accounts at about the middle of the time period considered by us. In fact, the returns on investment must be much more for the investment to be economically viable. We are using these values as the bare minimum. Our point would be even stronger with higher rates of return.

\section{Analysis of Data}

All the different tabulations that we have considered show a similar pattern of the variation of inflation faced at different levels of income. In all cases, there is a decrease in inflation with a rise in income levels. Thus the analysis is independent of the mode of data disaggregation.

We take the household level first. Tables 1-4 show that the households in the lowest three income groups resort to negative savings in order to meet their consumption expenditures. Our findings are supported by the report of the micro-nutrient survey conducted by the Planning Commission $[12 ; 13]$. Unfortunately, the survey report gives no information about the sources of the funds which help to meet the expenditure in excess of the incomes of households. It appears reasonable to assume that the extra consumption expenditures are met mainly through borrowing. This is admittedly only an approximation, but perhaps a good approximation. Of course, interest has to be paid on this borrowed money one way or another. Often enough, the low-income groups borrow from money-lenders and other non-commercial bank ing sources where the rates of interest are many times as high as the official rates. However, we shall use the two interest rates considered earlier as the barest minimum rates. The 12-percent interest rate was close to the lowest bank lending interest rate at the time under consideration. At the extreme ends of the income groups in Tables $1-4$, it is not clear how seriously to take the actual numbers. There are grave problems of misreporting and of even interpretation in these cases. They should be taken as indicating a trend rather than an exact value.

In Table 1, for the whole of Pakistan, we find that the lowest-income group considered by us experienced an inflation rate of 24.4 percent. At the rate of 6.5 percent, the loss of income to the lowest-income group through negative savings wil amount to 5.8 percent and at the rate of 12 percent, it will amount to 10.8 percent. Adding the loss of income through interest on borrowing to the loss through inflation faced, we find that the households in the lower-income groups face an inflation rate of 30.2 percent in the first case and of 35.2 percent in the second case. In the same table the highest-income group considered faces an inflation of 4.9 percent This group having money left over after expenditures resorts to savings. The addition to income amounts to -3.8 percent through the first interest rate and to -7.00 percent through the second rate. The net inflation faced is -1.1 percent at the firs rate and -2.1 percent at the second rate. Remember that the negative inflation rate merely means that spending power is increasing overall instead of decreasing. 


\section{Table 2}

Effective Inflations I and II for Urban and Rural Households in Different Income Groups

Urban Households

Monthly Income Groups

\begin{tabular}{cc}
\hline Effective & Effective \\
Inflation I & Inflation II
\end{tabular}
Rural Households

(2)

(3)

(4)

(5)

\begin{tabular}{lrrrr}
\hline \multicolumn{1}{c}{$(1)$} & $(2)$ & $(3)$ & $(4)$ & $(5)$ \\
\hline Rupees & & & & \\
$100-199$ & 37.0 & 43.3 & 29.4 & 34.1 \\
$200-299$ & 21.0 & 23.0 & 19.2 & 21.0 \\
$300-599$ & 16.0 & 16.8 & 12.9 & 12.9 \\
$600-999$ & 12.3 & 12.2 & 7.9 & 6.5 \\
$1000-1499$ & 11.4 & 11.1 & 7.5 & 6.1 \\
$1500-2099$ & 9.3 & 8.1 & 2.3 & -0.7 \\
$2100-3599$ & 5.0 & 2.9 & 4.6 & 2.6 \\
$3600>$ & 3.3 & 0.7 & -3.2 & -7.7 \\
\hline
\end{tabular}

Table 3

Effective Inflations I and II, Overall per capita, Urban per capita and Rural per capita, for Different Income Groups

\begin{tabular}{|c|c|c|c|c|c|c|}
\hline \multirow{3}{*}{$\begin{array}{l}\text { Monthly } \\
\text { Income } \\
\text { Groups }\end{array}$} & \multicolumn{2}{|c|}{ Overall per Capita } & \multicolumn{2}{|c|}{ Urban per Capita } & \multicolumn{2}{|c|}{ Rural per Capita } \\
\hline & Effective & Effective & Effective & Effective & Effective & Effective \\
\hline & $\begin{array}{c}\text { Inflation } \\
\text { I }\end{array}$ & $\begin{array}{c}\text { Inflation } \\
\text { II }\end{array}$ & $\begin{array}{c}\text { Inflation } \\
\text { I }\end{array}$ & $\begin{array}{c}\text { Inflation } \\
\text { II }\end{array}$ & $\begin{array}{c}\text { Inflation } \\
\text { I }\end{array}$ & $\begin{array}{c}\text { Inflation } \\
\text { II }\end{array}$ \\
\hline
\end{tabular}

\begin{tabular}{lrrrrrr}
\hline \multicolumn{1}{c}{$(1)$} & $(2)$ & $(3)$ & $(4)$ & $(5)$ & $(6)$ & $(7)$ \\
\hline Rupees & & & & & & \\
$20-39$ & 32.2 & 37.6 & 43.5 & 51.6 & 29.7 & 34.6 \\
$40-59$ & 17.5 & 18.7 & 19.0 & 20.5 & 16.3 & 17.1 \\
$60-79$ & 15.9 & 16.7 & 18.1 & 19.4 & 14.0 & 14.3 \\
$80-199$ & 10.2 & 9.4 & 12.1 & 11.9 & 8.1 & 6.7 \\
$200-499$ & 8.5 & 7.3 & 9.0 & 8.1 & 7.0 & 5.3 \\
$500-999$ & 4.7 & 2.5 & 4.8 & 2.6 & 4.6 & 2.2 \\
$1000>$ & -0.2 & -3.9 & 1.2 & -2.1 & -4.6 & -9.6 \\
\hline
\end{tabular}

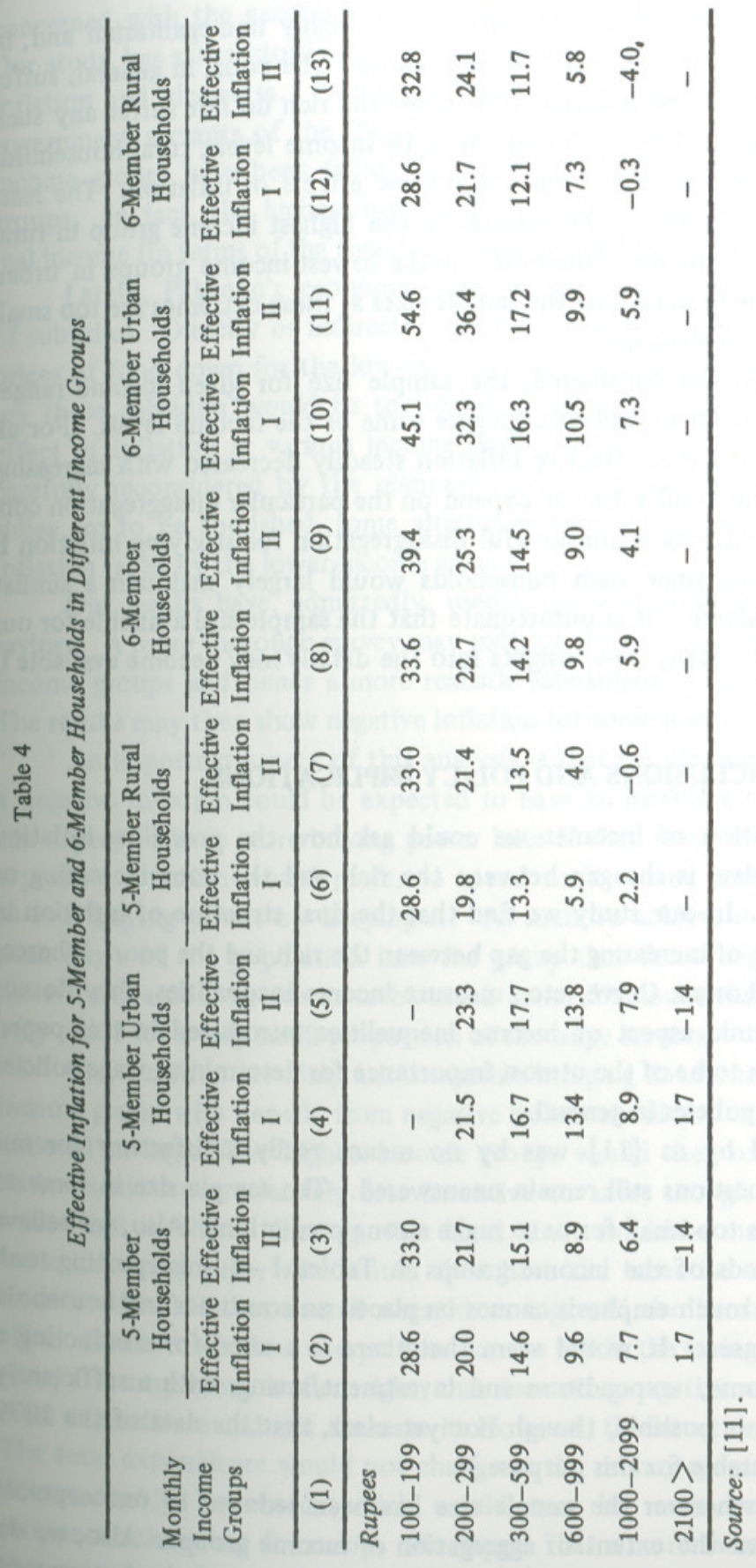


It is apparent that the effects of inflation are highly non-egalitarian and, in fact, contribute to increasing the existing inequalities. The poor, in general, suffer a loss of income through high inflation rates while the rich do not suffer any such loss of income. Tables 1-4 show that at the same income levels, rural households suffer less than urban households from the adverse effects of inflation. The least hit by inflation appear to be the households in the highest income group in rural areas and the worst off are the households in the lowest-income groups in urban areas. It must be borne in mind that the sample sizes at these extremes are too small to allow a more definitive analysis.

In the disaggregations considered, the sample size for given income ranges was often too small and so we had to aggregate some of the income levels. For all disaggregations, we found that effective inflation steadily decreased with increasing income levels. Thus our results do not depend on the particular disaggregation considered. In our view, the most meaningful disaggregation for studying inflation is by fixed-size households since such households would largely maintain a similar consumer behaviour pattern. It is unfortunate that the sample size available for our analysis was so limited. Many new insights into the details may become available if larger samples are used.

\section{CONCLUSIONS AND POLICY IMPLICATIONS}

Given a distribution of incomes we could ask how the prevailing inflation affects it. In particular, is the gap between the rich and the poor increasing or decreasing over time? In our study we find that the dual structure of inflation in Pakistan has the effect of increasing the gap between the rich and the poor. Whereas the Gini Coefficient, Lorenz Curve, etc., measure income inequalities, they do not touch upon the dynamic aspect of income inequalities introduced in this paper. This aspect would seem to be of the utmost importance for determining wage policies in particular, and fiscal policies in general.

The survey used by us [11] was by no means really satisfactory for our purposes and many questions still remain unanswered. The sample size in some of the disaggregations was too small for us to make strong predictions. Also, we believe that at the extreme ends of the income groups in Tables 1-4, misreporting took place, and as such too much emphasis cannot be placed on consumer and household behaviour for these cases. It would seem that there is a need for conducting a detailed servey of income, expenditure and investment/saving, with a sufficiently large sample size. (It is possible, though not yet clear, that the data of the 1979 survey [10] might be usable for this purpose.)

For our study, wherever the sample size has been reduced to unacceptable levels we have increased the extent of aggregation of income groups. Also, we do not place too much reliance on the actual statistics in the first and the last rows of Tables $1-4$, and take them to be only trend indicators. Our study is anyhow concerned with the general trend in the effect of inflation across income groups. Our study has satisfactorily shown that higher income groups face a lower effective Our study hice-versa. Preliminary results of a study of increase in the wages of government servants of the Punjab [5] indicate that the real wages of the lowerincome groups have been falling far more rapidly than those of the higher-income groups. In fact, the highest income groups appear to have enjoyed an increase in real income (in terms of the spending power available).

Lately, Pakistan's economic policies have been directed towards withdrawal of subsidies. Directly or indirectly, most of these subsidies are designed to keep the prices of food down for the low-income consumer. Clearly, the effect of withdrawing these subsidies would be to further enhance the enormous differences in the effect of inflation at various income levels. Such a serious consequence should be carefully reconsidered by the planners in the light of the above findings. If subsidies are to be abolished, some alternative means must be found for reducing the inflation faced by the lower-income groups.

Our results have, admittedly, used the lowest possible values for returns on savings. A more thorough survey may indicate the nature of investment for different income groups and hence a more realistic assessment of the returns on investment. The results may then show negative inflation for some lower-income groups as well.

An important aspect of this analysis is that people facing what we have called a negative inflation could be expected to have an incentive to save. After all, they can expect to have more buying power later if they save. However, those who face a positive inflation would prefer to spend their money earlier as they will expect to lose buying power by keeping it. As such, to achieve more saving, we need to push more of the population into the group that faces 'negative inflation'. Nevertheless, there does not seem to be much room for doubt that negative inflation will only occur for a very small proportion of the wage earners.

The question certainly arises whether bringing down the income of the highestincome group who benefit from negative inflation will not raise the total quantity of national savings. The highest-income groups would then have a lower negative inflation and hence relatively less incentive to save, though the incentive to save would still be there. On the other hand, there would be many more people in the lower-income groups, who would then have the incentive to save. We must also consider the fact that overall negative savings will also be drastically reduced. This effect should more than compensate for the fall in the savings of the highest-income groups. It may seem, at first sight, that decreasing negative savings will only increase total expenditure and not decrease it. However, the situation is not really so simple. The total expenditure would not change as the money spent by the 'negative savers' is presumably borrowed, which would now be made available for investment purposes rather than for usury. We expect that a more thorough study would show that reducing inflation inequalities leads to an increase in national savings. 


\section{REFERENCES}

1. Afridi, Usman, and Asghar Qadir. "Dual Sector Inflation in Pakistan". Pakistan Development Review. Vol. XXII, No. 3. Autumn 1983.

2. Afridi, Usman, and Asghar Qadir. "Dual Sector Inflation and UnderDevelopment". (In preparation)

3. Bach, G. L., and J. Stephenson. "Inflation and the Redistribution of Wealth". Review of Economics and Statistics. Vol. 56. 1974.

4. Hansen, Bent. A Study in the Theory of Inflation. London: George Allen and Unwin. 1951.

5. Hussain, Asad. "The Effects of Price Increases on Income Levels of Government Employees of the Punjab". (In preparation)

6. Keynes, J. M. The General Theory of Employment, Interest and Money. London: Macmillan. 1936.

7. Keynes, J. M. How to Pay for the Water? London: Macmillan. 1940.

8. Muellbauer, J. "Prices and Inequality: The United Kingdom Experience". Economic Journal. March 1974.

9. Nordhaus, William D. "The Effect of Inflation on the Distribution of Economic Welfare". Journal of Money, Credit and Banking. Vol. 5. 1973.

10. Pakistan. Statistical Division. Household Income and Expenditure Survey, 1979. Islamabad. 1981.

11. Pakistan. Planning and Development Division. Nutrition Cell. Tape of Data Pertaining to the Micro-Nutrient Survey of Pakistan, 1976-77. Islamabad.

12. Pakistan. Planning and Development Division. Nutrition Cell. MicroNutrient Survey of Pakistan, 1976-77. Vol. I. Islamabad. June 1978.

13. Pakistan. Planning and Development Division. Nutrition Cell. MicroNutrient Survey of Pakistan, 1976-77. Vol. II. Islamabad. December 1979.

14. Piachaud, D. "Prices and Distribution of Incomes". Evidence submitted to the Royal Commission on the Distribution of Income and Wealth. 1976.

15. Qadir, A., and K. Qadir. "Inflation in a Growing Economy". Pakistan Economic and Social Review. Vol. 19, No. 2. 1981.

16. Smithies, A. "The Behavior of Money National Income under Inflationary Conditions". Quarterly Journal of Economics. Vol. 56. November 1942.

17. Williamson, J. G. "Strategic Wage Goods, Prices and Inequality". American Economic Review. March 1977. 


\section{Comments on \\ "Effects of Dual Sector Inflation Across \\ Income Levels in Pakistan"}

I think that the model used in this paper is robust. By this I mean that my comments and criticism do not undermine it. The literature review, however, is weak and superficial. It does not do justice to any of the schools of thought mentioned. The authors may well give a review of recent literature on this complex subject or do a more in-depth review on the specific issue of concern.

Inflation has been calculated as the weighted average of inflation faced by different parts of the agents income. Essentially the authors' concern is to estimate the net burden of inflation on different income groups resulting from the allocation of their budget to the three different categories cited in the equation below.

$$
\dot{P}_{A}^{i}=\alpha^{i} P_{F}+\beta^{i} \dot{P}_{N F}+\gamma^{i} r
$$

where

$$
\begin{aligned}
& A=\text { Average } \\
& F=\text { Food } \\
& N F=\text { Non-food } \\
& \gamma=\text { Savings/lending portion of the budget } \\
& i \quad \text { Income group } \\
& r \quad=\text { Interest rate } \\
& \quad \alpha+\beta+\gamma=1
\end{aligned}
$$

Note: For borrowers, $r>0$, and for lenders, $r<0$. 
In another paper the authors have calculated separate inflation rates for the food and non-food sectors. The food sector contains basic crops. The authors' data source could be questioned here as could be the relative weights that result for the different items of food that go into calculating the average $P$. This has been done in an earlier seminar and so I by-pass this issue.

Similarly, one can question the non-food items in the calculation of the average $\dot{\mathrm{P}}$. Here the reservations may be more serious. The authors do justify exclusion of cement, but real estate and jewellery are important alternatives to saving and this may be a serious omission.

The third component of income is capital. The authors argue that what is not consumed as $F$ or $N F$ must be saved or invested. Hoarding is ignored here. Only when hoarded income is pulled into calculation and expended on $F$ or $N F$ in the same pattern as the average ratio for the $i$ th group is there no bias in the estimates.

The authors claim that they can not get a handle on investment; so they assume that the return on saving is an adequate proxy. When capital markets are perfect, then in a static state equilibrium $r$ is equal to profits plus an uncertainty premium. It may be unrealistic to assume this for Pakistan. In general, capital markets are not perfect and the capital rationing the lending rate of interest may be far below profits.

The model itself appears to have some theoretical flaws. It is assumed that $r$ and $\dot{P}$ are simply additive in a linear fashion to ascertain $\dot{P}_{A}^{i}$. This is incorrect because $r$ and $\dot{P}$ are simultaneously determined in a macro context. If $r$ is fixed exogenously, this assumption is less unrealistic.

Also, in this linear equation what the authors may want to be concerned with is the real and not the nominal $r$; i.e.

$$
\dot{P}_{A}^{i}=\alpha^{i} \dot{P}_{F}+\beta^{i} \dot{P}_{N F}+r^{i}\left(r-\delta^{i}\right)
$$

where

$$
\delta^{i}=\alpha^{i} \dot{P}_{F}+\beta^{i} \dot{P}_{N F}
$$

So for lenders, only if $r>\delta^{i}$, is the rate at which the purchasing power of the $i$ th income group eroded negative, and therefore "effective" inflation lessened.

The basic approach of the authors is simple (which I consider a virtue), novel, and interesting. I think this is overall a useful contribution for attempting to assess income distributional aspects of inflation. 